http://ua.textreferat.com/referat-1167.html;

http://otherreferats.allbest.ru/;

http://womanadvice.ru/konservirovannye-persiki;

http://www.coolreferat.com/.

Комп ютерний технолог. Ваше завдання: за допомогою технічних засобів розробити мультимедійну презентацію.

Інтернет-ресурси з мультимедіа-презентаціями:

http://images.yandex.ua/;

http://www.youtube.com/;

http://video.yandex.ua/\#top;

http://gotovim-doma.ru/view.php?g=6

Отже, досвід показав, що методика веб-квест користується високою популярністю в сучасних учнів, активізує їх, сприяє підвищенню якості навчання. Веб-квест - це вид проектної діяльності, в межах якої вчитель формує пошукову діяльність школярів, задає їм параметри цієї діяльності й визначає ії час. Означена технологія перетворює учнів з пасивних об'єктів навчальної діяльності в їі активних суб'єктів, підвищує мотивацію до процесу «здобування» знань.

Отже, веб-квест технологія - це сукупність методів та прийомів організації дослідницької діяльності, для виконання якої учні на уроках трудового навчання здійснюють пошук інформації, використовуючи інтернет-ресурси 3 практичною метою. Така технологія дозволяє працювати в групах, розвиває конкурентність та лідерські якості школярів, підвищує не тільки мотивацію до процесу здобування знань, а й відповідальність за результати діяльності та їх презентацію. Цю технологію можна використовувати незалежно від навчальної дисципліни, головне - мати доступ до Інтернету.

\title{
Література
}

1. Быховский Я. С. Образовательные веб-квесты / Я. С. Быховский [Электронный ресурс]. - Режим доступа : http: // ito.edu.ru 2. Кононец Н. Технологія веб-квест у контексті ресурсно-орієнтованого навчання студентів/ Н. Кононец // Витоки педагогічної майстерності: збірник наукових праць Полтавського національного педагогічного університету імені В.Г. Короленка. - Вип. 10. Полтава, 2012. - Серія «Педагогічні науки». - С. 138-143. 3. Трайнев В. А. Информационные коммуникационные педагогические технологии (обобщение и рекомендации) : [учеб. пос.] / В. А. Трайнев, И. В. Трайнев. - М. : Изд.-торг. корп. «Дашков и Ко», 2008. - 280 с.

\section{АКТИВІЗАЦІЯ ПІЗНАВАЛЬНОЇ ДІЯЛЬНОСТІ УЧНІВ НА УРОКАХ ТРУДОВОГО НАВЧАННЯ: РЕЗУЛЬТАТИ ЕКСПЕРИМЕНТУ}

Сушенцев О. С. Активізація пізнавальної діяльності учнів на уроках трудового навчання: результати експерименту.

У статті автор розкриває хід дослідно-експериментальної роботи 3 перевірки визначених теоретичним шляхом педагогічних умов активізації пізнавальної діяльності учнів основної школи на уроках трудового навчання.

Ключові слова: активізація пізнавальної діяльності, пізнавальна активність, пізнавальна самостійність, трудове навчання. 
Сушенцев А. Е. Активизация познавательной деятельности учеников на уроках трудового обучения: результаты эксперимента.

В статье автор раскрывает ход опытно-экспериментальной работы по проверке определенных теоретическим путем педагогических условий активизации познавательной деятельности учащихся основной школы на уроках трудового обучения.

Ключевые слова: активизация познавательной деятельности, познавательная активность, познавательная самостоятельность, трудовое обучение.

Sushentsev O. Ye. Activization of schoolchildren's cognitive activity during labor training classes: experiment results.

The author reveals the course of test work on checking theoretically defined pedagogical conditions of promoting cognitive activity of schoolchildren during labor training classes.

Key words: activization of cognitive activity, cognitive activity, cognitive independence, labor training.

Основною метою трудового навчання $€$ формування технічно, технологічно освіченої особистості, підготовленої до життя й активної трудової діяльності в умовах сучасного високотехнологічного, інформаційного суспільства, життєво необхідних знань, умінь i навичок. У цих умовах успішна реалізація педагогічних закономірностей під час побудови і вдосконалення навчально-виховного процесу передбачає врахування досить складного взаємозв'язку цілої низки чинників, що відображають співвідношення в системі «учитель- учень». У цій системі взаємозв’язку учитель $є$ ланкою, яка спрямовує та стимулює навчально-пізнавальну діяльність учня. Важливим чинником успішної взаємодії між учителем і учнем $\epsilon$ активна пізнавальна діяльність учнів. Саме в ній полягає є головний сенс організації навчального процесу в загальноосвітній школі, оскільки становлення учня як суб'єкта діяльності у процесі учіння забезпечує його активну життєву позицію не тільки в роки навчання, але і в майбутньому самостійному житті.

Метою статті $є$ висвітлення результатів експериментальної перевірки ефективності педагогічних умов, що забезпечують активізацію пізнавальної діяльності учнів на уроках трудового навчання.

У силу специфічності і складності предмета дослідження та неможливості точного вираження його результатів у формі кількісних показників, критеріальними характеристиками ми визначили зміни в чинниках, які зумовлюють активність пізнавальної діяльності учнів.

На етапі констатувального експерименту ставилися такі завдання: дослідити проблему активізації пізнавальної діяльності у психолого-педагогічній теорії та практиці; розкрити засоби активізації пізнавальної діяльності учнів загальноосвітньої школи; визначити й теоретично обгрунтувати педагогічні умови, що сприяють активізації пізнавальної діяльності учнів на уроках трудового навчання; визначити критерії ефективності запропонованої технології активізації пізнавальної діяльності учнів; провести констатувальну діагностику та узагальнити ії результати.

Для формування експериментальної та контрольної груп нами було проведене на уроках трудового навчання (технічна праця) вхідне тестування учнів 5-9 класів задля виявлення залишкових знань i умінь та було здійснене спостереження за їх пізнавальною діяльністю. Практичне розв'язання завдань дослідження потребувало вивчення готовності вчителів трудового навчання до активізації пізнавальної 
діяльності учнів.

Ми вважали за необхідне з'ясувати: усвідомлення вчителями сутності пізнавальної діяльності; особистісне ставлення вчителів до необхідності активізувати процес учіння; знання засобів, що активізують пізнавальну діяльність учнів на уроках трудового навчання. Для фіксації та об'єктивної інтерпретації й оцінки визначених параметрів, було виділено низку ознак, які характеризували ступінь прояву кожного 3 них. 3 цією метою відвідано й обговорено уроки трудового навчання, проведено бесіди, анкетування, ранжування.

Як свідчить теоретичний аналіз науково-педагогічної літератури і практика, на активізацію пізнавальної діяльності учнів впливають багато чинників, роль яких неоднозначна, що й поставило нас перед необхідністю проведення дослідження найважливіших із них. Для розв'язання цього завдання вчителям трудового навчання було запропоновано анкету, у якій ставилось завдання проранжувати 15 чинників. Аналіз ранжування виявив таке. Переважна більшість учителів серед чинників, що активізують пізнавальну діяльність учнів, надала перевагу матеріально-технічній базі, відвівши їй перший ранг (238 балів). На другому місці знаходиться чинник «проблемне навчання» (236 балів), на третьому місці знаходиться чинник «педагогічне стимулювання пізнавальної діяльності учнів» (221 бал), четверте місце посів чинник «активні методи навчання» (212 балів), на п'ятому місці - чинник «мотивація навчально-трудової діяльності» (206 балів). Найменш вагомим (15 ранг), що впливає на пізнавальну активність учнів, на думку вчителів трудового навчання, виявився чинник «система дидактичних принципів» (106 балів).

Таким чином було встановлено, що вчителі трудового навчання по-різному ставляться до проблеми активізації пізнавальної діяльності учнів і по-різному визначають чинники, що на неї впливають. Це, на нашу думку, дало можливість стверджувати, що для того щоб учителі більш ефективно могли оцінити запропоновану технологію активізації пізнавальної діяльності, вони повинні мати певний рівень знань щодо засобів активізації пізнавальної діяльності та вмінь визначати і створювати відповідні педагогічні умови для підвищення активності учнів на уроці трудового навчання.

3 огляду на це, ми вважали доцільним закцентувати увагу на необхідності надання методичної допомоги вчителям трудового навчання, які будуть залучені до дослідно-експериментальної роботи (проведення семінарів, відвідування й обговорення уроків тощо).

Для практичного розв'язання завдань дослідження постала необхідність визначення критеріїв, які б давали можливість виявити рівень сформованості пізнавальної активності учнів на етапі констатувальної діагностики, прослідкувати іiі динаміку в ході формувального експерименту і здійснити порівняльний аналіз.

У педагогічній теорії $є$ кілька підходів до рокриття поняття «критерій». Так, Є. Рапацевич уважає, що критерій - «це ознака, на основі якої здійснюється оцінка чого-небудь; мірило; умовна прийнята міра, що дозволяє здійснити вимірювання об'єкта і на підставі цього дати йому оцінку» [2, с. 271]. Проте для оцінки результатів будь-якого педагогічного процесу треба використовувати критерії, що відповідають досягненню поставленої мети.

В. Ягупов під критеріями розуміє ті якості явища, що відбивають його істотні характеристики і саме тому вони підлягають оцінці. Автор підкреслює, що «критерії практично визначають зміст і перебіг навчально-пізнавальної діяльності учнів та безпосередньо встановлюють її результативність» [5, с. 411].

До кожного критерію нами були розроблені показники, за якими ми оцінювали 
стан проблеми. Виходячи із зазначеного вище, у якості критерію активізації пізнавальної діяльності учнів ми визначили готовність учня до пізнавальної діяльності. При цьому ми виходили з того, що готовність, як складне психологічне утворення, містить такі компоненти: мотиваційний, орієнтаційний, операційний, емоційно-вольовий, оціночний.

Визначення готовності виконувалось на основі модифікованої нами методики, розробленої О. Новіковим. Згідно з цією методикою здійснювалась оцінка за такими показниками: позитивне ставлення до пізнавальної діяльності, інтерес до неї; знання сутності і змісту пізнавальної діяльності; володіння способами і прийомами пізнавальної діяльності; емоційний стан у процесі діяльності та самоконтроль, саморегуляція; самооцінка власної пізнавальної діяльності.

Оцінка здійснювалась за 10-бальною шкалою. Найвищий рівень сформованості певного показника оцінювався в 10 балів, найнижчий - 1 бал. Учень, який має високий рівень готовності, може отримати максимальну кількість балів - 60, учень, який не виявляє готовності - 6 балів. Між цими межами розміщені рівні готовності: низький рівень - від 6 до 18 балів; середній - від 19 до 35 балів; високий - від 36 до 60 балів. Оцінка готовності учнів до пізнавальної діяльності була піддана ретельному аналізу з використанням якісних і кількісних характетристик у сукупності і дала можливість отримати дані, як загалом по контингенту досліджуваних, так і визначити особливості індивідуального рівня готовності кожного учня.

Аналіз отриманих результатів готовності учнів до пізнавальної діяльності дозволив встановити, що на початковому етапі учні контрольних і експериментальних класів не мають суттєвих відмінностей. Так, високий рівень готовності виявили 19,0 \% учнів контрольних класів (група А) і 22,8 \% експериментальних (група Б). Середній рівень виявили відповідно 38,0 \% та 31,7\% респондентів. Низький рівень готовності характерний для 43,0 \% учнів контрольних та 45,5 \% експериментальних класів.

Стан готовності показав, що у більшості з учнів відсутній інтерес до пізнавальної діяльності, який, на нашу думку, пов'язаний 3 низьким рівнем володіння знаннями сутності і змісту пізнавальної діяльності та способами і прийомами її здійснення.

Слід зазначити, що у значної частини учнів процес пізнавальної діяльності супроводжується негативними емоційними станами: розгубленість, тривожність, знервованість, песимізм, а інколи навіть роздратованість і нетерпимість, з якими учні не спроможні справитись в силу несформованості умінь саморегуляції.

Визначаючи пізнавальну самостійність як критерій, ми керувалися вираженою Т. Шамовою [3], Г. Щукіною [4], І. Лернером [1] 3 приводу того, що активність (вираження ставлення до змісту і процесу пізнання) є складником самостійності як способу реалізації цього ставлення в дії. Тому одним із критеріїв ефективності запропонованої технології активізації пізнавальної діяльності учнів було визначено пізнавальну самостійність.

Під час визначення рівня пізнавальної самостійності учнів нами було проведено спостереження за практичною діяльністю учнів, бесіди, аналіз продуктів їх діяльності. Для фіксації та інтерпретації результатів дослідження на кожного учасника експерименту був оформлений оціночний лист, куди вносились отримані на констатувальному етапі дані і подальші зміни.

Аналіз результатів свідчить, що в реальній практиці трудового навчання, що склалася у школі, не спостерігається бажаного рівня пізнавальної самостійності учнів: тільки $24 \%$ учнів контрольних класів та $22 \%$ експериментальних проявляють високий рівень пізнавальної самостійності. Водночас, практично кожен третій учень в 
обох групах демонструє низький рівень пізнавальної самостійності. Учні із середнім рівнем самостійності склали $41,3 \%$ в контрольних класах $\mathrm{i} 43,0 \%$ в експериментальних. Отже, прослідковується певна невідповідність між вимогами пізнавальної діяльності до рівня пізнавальної самостійності учнів (на основі якої будується процес учіння) і фактичним рівнем ії сформованості.

Виходячи 3 того, що пізнавальна активність багатьма науковцями розглядається як мета діяльності, як засіб ii досягнення і як результат, активізацію пізнавальної діяльності учнів слід розуміти як мобілізацію вчителем інтелектуальних, вольових і фізичиних сил учнів для досягнення конкретних навчальних цілей. Тобто активізацію процесу учіння можна розглядати як процес і результат стимулювання активності учнів у пізнавальній діяльності. А пізнавальна активність в такому разі $є$ результатом активної пізнавальної діяльності, у якій відбувається не тільки засвоєння знань, умінь та навичок, але й формується емоційно-оцінне ставлення до процесу і результату пізнання. Виходячи 3 цього в нашому дослідженні пізнавальна активність постає критерієм активної пізнавальної діяльності, а її інтегрованим показником засвоєнні знання та сформовані уміння і навички. Під час визначення рівнів і показників ми орієнтувалися загально прийнятими «Критеріями оцінювання навчальних досягнень учнів з трудового навчання».

Аналіз рівня сформованості трудових умінь дав підстави для висновку про те, що чинна система трудового навчання учнів мало ефективна в плані досліджуваної нами проблеми. Найбільшчисленну групу складають учні 3 низьким рівнем сформованості трудових умінь як у контрольних, так і експериментальних групах (відповідно 47,1 \% і 48,8 \%). Достатнім рівнем характеризується тільки кожен сьомий учень. Учнів, у яких практично не розвинуті трудові уміння, не виявлено. Аналіз рівня розвитку окремих трудових умінь свідчить про їх сформованість різною мірою.

Порівнюючи результати засвоєння знань і виконання практичного завдання, ми виявили, що теоретичні знання деяких учнів вищі, ніж їхні трудові уміння й навички, $\mathrm{i}$ навпаки. Це пояснюється тим, що під час навчального процесу вчитель частіше орієнтується на середнього учня, не виокремлюючи сильніших чи слабших. Так, наприклад, учні, які мають високий рівень знань теоретичного матеріалу, отримують достатній, а іноді й середній рівень під час виконання практичних завдань тому, що одержують трудові завдання, які не відповідають їхнім можливостям. Часто, на жаль, ці учні стають пасивними, інертними, втрачають інтерес до виконання практичного завдання. А слабші учні, навпаки, за браком необхідних теоретичних знань, не можуть виконати практичне завдання, яке не відповідає їхнім можливостям. Такі учні часто закомплексовані, невпевнені в собі. Тому, щоб уникнути небажаної шаблонності, необхідно для кожної динамічної мікрогрупи розробляти посильні, цікаві трудові завдання, що й було зроблено у процесі експерименту.

Під час визначення рівня активності використовувались різнорівневі тестові завдання; залучення учнів до: визначення мети і завдань, проектування подальшої діяльності, постановки запитань, обговорення результатів виконання завдань, спостереження.

Як свідчать узагальнені результати, найбільш чисельну групу складають учні 3 репродуктивним рівнем (низьким) пізнавальної активності як в експериментальному, так і в контрольному класах, у той час як творчий рівень (високий) характеризує тільки 10,6 \% учнів експериментальної та 11,6 \% контрольної групи.

Отже, при всій відносності отриманих результатів все ж таки вони відображають об'єктивні тенденції і дозволяють констатувати, з одного боку, задовільний рівень розуміння учнями значущості пізнавальної діяльності, а 3 іншого,- низький рівень 
активності, яку вони виявляють у пізнавальній діяльності.

Вивчення досліджуваної проблеми в педагогічній теорії та практиці, результати констатувального експерименту дозволили нам зробити висновок щодо необхідності пошуку нових підходів до підвищення активності учнів основної школи на уроках трудового навчання.

Задля перевірки гіпотези дослідження був організований i проведений формувальний експеримент, спрямований на активізацію пізнавальної діяльності учнів шляхом організації цілеспрямованого формування пізнавальної активності. Для проведення дослідно-експериментальної роботи була створена модель активізації пізнавальної діяльності учнів та розроблена технологія формування пізнавальної активності учнів на уроках трудового навчання.

На етапі формувального експерименту з учителями трудового навчання, які залучались до проведення експерименту, були проведені тематичні семінари «Сутність активізації пізнавальної діяльності учнів на уроках трудового навчання» та «Фактори, що впливають на рівень активності учнів на уроці трудового навчання». Експертам було запропоновано проранжувати за значущістю визначені нами теоретичним шляхом педагогічні умови, які будуть сприяти підвищенню пізнавальної активності учнів на уроках трудового навчання. Таким чином було усунено випадковість у визначенні педагогічних умов, що будуть сприяти активізації пізнавальної діяльності учнів на уроках трудового навчання.

Отже, педагогічним умовами активізації пізнавальної діяльності учнів ми визначили: систематичний, цілеспрямований розвиток мотивації навчально-трудової діяльності учнів; створення «ситуації успіху» в пізнавальній діяльності; диференціація процесу навчання; організація проблемного навчання; використання методичної комп'ютерно-орієнтованої системи навчання.

Виходячи 3 даних, отриманих у результаті діагностування початкового рівня сформованості пізнавальної активності в учнів експериментальних класів, була проведена їх диференціація залежно від рівня сформованості пізнавальної активності. Так, під час роботи з учнями 3 низьким рівнем основна увага зверталася на оволодіння знаннями, вміннями, навичками, формування позитивного ставлення до пізнавальної діяльності. 3 учнями, які виявили середній рівень, головна увага в процесі формувального експерименту приділялась формуванню вмінь використовувати знання на практиці, здійснювати самоаналіз і самоконтроль. У роботі з учнями 3 високим рівнем сформованості пізнавальної активності основна увага зосереджувалася на формуванні творчих здібностей.

Виявлення змін за критеріями, що були визначені на етапі констатувального експерименту, передбачало порівняльне співвідношення їх рівнів в учнів експериментального і контрольного класів до початку формувального експерименту i після нього.

Аналіз експериментальних даних за першим критерієм показав, що за відносно однакового рівня готовності до пізнавальної діяльності, зафіксованого на констатувальному етапі, на заключному мали суттєві розходження в учнів експериментального і контрольного класів.

Результати контрольного діагностування рівня готовності учнів до пізнавальної діяльності засвідчили, що кількість учнів експериментальних класів (гр.Б), які виявили високий рівень готовності до пізнавальної діяльності складає 31,7 \%, проти 22,8 \% на етапі констатувального експерименту. Відбулися значні зміни в групі 3 низьким рівнем сформованості готовності до пізнавальної діяльності, про що свідчить зменшення кількості учнів на 27,6\%. 
Зміни в параметрах готовності до пізнавальної діяльності суттєво позначились на рівні сформованості пізнавальної самостійності учнів у експериментальних класах: 3 високим рівнем збільшилась $322,0 \%$ до 27,6\%; 3 низьким рівнем зменшилась 3 $35,0 \%$ до $17,9 \%$ за рахунок збільшення кількості учнів 3 середнім рівнем сформованості пізнавальної самостійності. Водночас у контрольній групі ці показники змінилася несуттєво. Так, кількість учнів контрольної групи з середнім рівнем сформованості пізнавальної самостійності зросла на 4,2\% за рахунок зменшення кількості учнів з низьким рівнем і частково з високим (3,3\% та 0,9\% відповідно).

Упровадження розробленої нами моделі та технології активізації пізнавальної діяльності учнів суттєво вплинуло на інтенсифікацію засвоєння знань, формування вмінь і навичок учнів на уроках трудового навчання. Після відповідної роботи в експериментальних класах кількість учнів 3 високим рівнем знань збільшилася на 9,8 \%, відповідно кількість учнів з низьким рівнем зменшилась майже в два рази.

Приблизно така ж ситуація спостерігається при порівняльному аналізі рівня сформованих умінь та навичок. Кількість учнів 3 високим рівнем сформованості умінь та навичок на формувальному етапі експерименту в експериментальній групі зросла на 7,3\%, тобто практично у півтора рази, тоді як у контрольній групі цей показник залишився без змін. Середній i достатній рівень в експериментальних класах збільшився (відповідно на $11,4 \%$ та $7,4 \%$ ) за рахунок зменшення низького рівня на $26,1 \%$ в експериментальних класах.

Інтегральним критерієм результативності дослідно-експериментальної роботи є пізнавальна активність, зміни в рівнях якої свідчать про ефективність запропонованої системи активізації пізнавальної діяльності учнів.

Порівняння даних, отриманих у формувальному експерименті, 3 показниками констатувального етапу експериментальної і контрольної груп дозволило зробити висновок про підвищення активності учнів у пізнавальній діяльності. Підтвердженням цьому є зростання на 16,2 \% кількості учнів експериментальної групи 3 творчим рівнем при відповідному зменшенні на 8,9\% кількості учнів 3 репродуктивним рівнем пізнавальної активності. При збереженні у контрольній групі значної частини учнів 3 репродуктивним рівнем (зменшення на 2,4\%), кількість учнів 3 творчим рівнем зросла всього на $0,8 \%$, а з продуктивним - на 1,6\%.

Результати проведеного дослідження ефективності педагогічних умов активізації пізнавальної діяльності учнів засвідчили, що вони забезпечують суттєві зміни в рівні готовності учнів до пізнавальної діяльності, у сформованості пізнавальної самостійності та сприяють суттєвому підвищенню якості знань, умінь та навичок учнів. Проте слід зауважити, що не на всіх учнів проведена експериментальна робота здійснила бажаний вплив. Це, як показало дослідження, учні, у яких відсутня спрямованість на навчальну діяльність. Тому назрілим $є$ питання про організацію більш тривалих занять, спрямованих на активізацію пізнавальної діяльності.

\section{Література}

1. Лернер И. Я. Изучение истории СССР в 9 классе / И. Я. Лернер // Вопросы активизации познавательной деятельности учащихся.- М. : АПН РСФСР, 1963.C. 50. 2. Педагогика: Большая современная энциклопедия / [авт.-сост. Рапацевич Е. С.]. - $\quad$ Мн. : Современное слово, 2005. - 720 с. 3. Шамова Т. И. Активизация учения школьников / Т. И. Шамова. - М. : Педагогика, 1982. - 208 с. 4. Щукина Г. И. Познавательный интерес в учебной деятельности школьника / Г. И. Щукина. - М. : Знание. - 1972. - 32 с. 5. Ягупов В. В. Педагогіка : [навч. посіб.] / В. В. Ягупов. - К. : Либідь, 2002. - 550 с. 